共軛組成の および $\gamma$ ステンレス混合鋼粉のメカニカルアロイング

木村 勇次次，鎌田 政智杄，高木 節雄饮2

丸1 九州大学大学院, $\bar{T} 812$ 福岡市東区箱崎6-10-1.

九州大学工学部材料工学科, $\overline{\mathbf{T}} 812$ 福岡市東区箱崎6-10-1.

\title{
Mechanical Alloying of Premixed $\delta$ and $\gamma$ Stainless Steel Powders with a Tie Lined Chemical Compositions
}

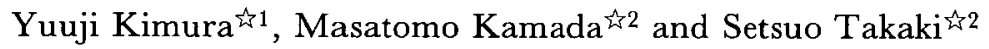 \\ 1. Graduate School, Kyushu University, 6-10-1 Hakozaki Higashi-ku, Fukuoka 812. \\ 42 Department of Materials Science and Engineering, Faculty of Engineering, Kyushu University, 6-10-1 \\ Hakozaki Higashi-ku, Fukuoka 812.
}

Received December 18, 1992

Mechanical alloying process of the mixture of ferritic( $\delta)$ and austenitic $(\gamma)$ stainless steel powders has been investigated by means of $X$-ray diffraction and EPMA line analysis. The chemical compositions of $\delta$ and $\gamma$ powders used is Fe-27mass\%cr7mass\%Ni and $\mathrm{Fe}-20$ mass\%Cr-12mass\%Ni, respectively, which are equilibrium compositions of $\delta$ and $\gamma$ phase at $1473 \mathrm{~K}$.

The $\gamma$ phase in the premixed $(\delta+\gamma)$ powders changes to bcc phase with ballmilling treatment and this phase change is promoted by increasing the volume fraction of $\delta$ powder. The structure of $\gamma-70$ vol\% $\delta$ premixed powder is of full bcc single phase after $360 \mathrm{ks}$ ball-milling treatment.

However, EPMA line analysis in premixed $(\delta+\gamma)$ powders with $360 \mathrm{ks}$ ball-milling treatment shows the inhomogeneity of the chenical composition of $\mathrm{Cr}$ and $\mathrm{Ni}$, while the structure is of bcc single phase. The inhomogeneity of chemical composition is deeply related to the phase transformation of $\gamma$. The structural change to bcc phase is mainly due to the deformation induced transformation of $\gamma$ to bcc martensite and partially due to the mechanical alloying at the interface between $\delta$ and $\gamma$ phase.

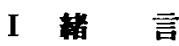

粉末治金法を利用して，超徽細な組織を有するフ

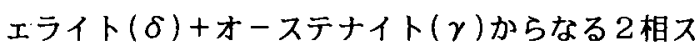
テンレス鋼を作製する手法の 1 つに， $\mathrm{Fe}-\mathrm{Cr}-\mathrm{Ni} 3$ 元 系状態図で共䡉組成の $\delta$ および $\gamma$ ステンレス鋼粉を
混合し，ボールミリングする方法が考えられる.

この手法では,ガスアトマイス法で得られる $\delta$ 単 相粉末をボールミリングにより強加工したのち高温 で $\delta$ 相と $\gamma$ 相の 2 相に相分離させる方法 ${ }^{1)}$ と比較し た場合，室温で $\delta$ 相と $\gamma$ 相が微細に混合した 2 相組 織が得られる可能性がある。しかも， $\delta$ と $\gamma$ 相の相 
比を容易に変化させることができるため, 合金粉の メカニカルアロイング過程を理解するうえでもこの 手法は有効である.

本報では， $1473 K$ で共覃する組成の $\delta$ 相と $\gamma$ 相の ステンレス鋼粉の混合粉について,ボールミリング 過程での粉末の組織変化を調查・検討し,この手法 で2相ステンレス鋼を作製するうえでの問題点を明 らかにした.

\section{II 試料およひ実蜸方运}

Fig. 1はFe-Cr-Ni3元系状態図の1473Kにおける等 温断面図を示す。図中の実線は文献値 2 ををプロット して得た結果であるが, タイライン上の合金におけ る化学組成と $\delta$ と相の相比の関係を詳細に検討し た結果 ${ }^{3)}, \gamma /(\delta / \gamma)$ 境界線は, 破線で示すよう にやや低Cr, 高 $\mathrm{Ni}$ 側に位置することが指摘されてい る.したがって実験には, 1473Kで共乾する粉末と して $27 \mathrm{mass} \% \mathrm{Cr}-7 \mathrm{mass} \% \mathrm{Ni}$ 組成の $\delta$ 鋼粉 (-150mesh) とFe-20mass\%Cr-12mass\%Ni組成の $\gamma$ 鋼粉 (-150mesh) を $\mathrm{N}_{2}$ ガスアトマイズ法で作製して用いた。用いた 鋼粉の化学組成をTable 1に示す.

ボールミリング処理は, $\delta$ と $\gamma$ 粉を所定の比率に 混合後, 直径 $15 \mathrm{~mm}$ の鋼球とともに容積3LのSUS304製 ポットに充填し, アルゴンガス雾囲気中で振動型ボ ールミリング装置を用いて, 種々のミリング時間で 少量の粉末を採取しながら最長 $360 \mathrm{ks}$ まで行った. なお, 粉末/鋼球の重量比は1/12である.

粉末断面の組織は, 粉末を冷間樹脂に埋め込んで バフ研磨仕上げしたのち, 酸性ピクリン酸アルコー ル溶液で腐食した試料について, 光学顕微鏡および SEMを用いて観察した. また, 同試料のCr, Ni合金元 素の線分析は, EPMA分析装置を用いて行った. 粉末 の基地相の同定ならびに定量はC 0 の $\mathrm{K} \alpha$ 線を用いた 粉末X線回折法により行った.

\section{III蛣果およひ考察}

Photo. 1は, $\gamma$-50vol\% $\delta$ 混合粉末を (a) $10.8 \mathrm{ks}$ ， (b) $36 \mathrm{ks}$, (c) $108 \mathrm{ks}$ および (d) $360 \mathrm{ks}$ ミリング 処理した粉末の断面の組織を示す. いずれの写真 でも腐食部は $\delta$ 相, 白色部は $\gamma$ 相に対応する. ミ リングの初期で粉末同士が圧接 ・ 鐉造されて $\delta$ 粉 と $\gamma$ 粉が交互に積み重なった層状組織が形成された のち, ミリングの 時間が長くなるにつれて粉末内 部の組織の均一化ならひに微細化が進行する傾向に

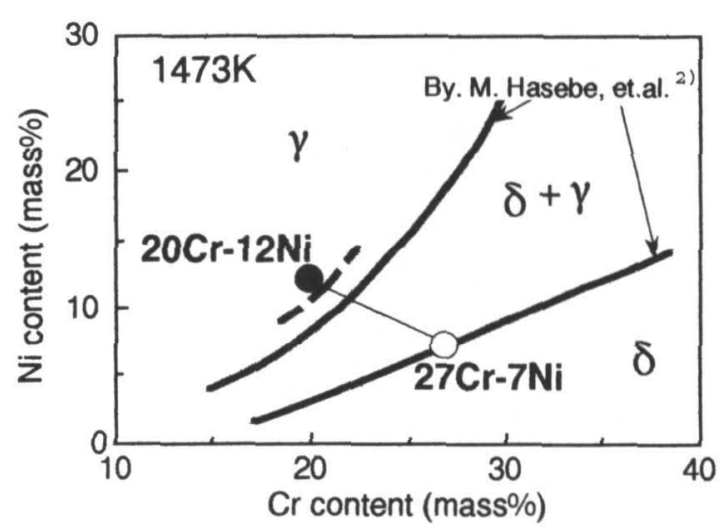

Fig. 1 Isothermal diagram at $1473 \mathrm{~K}$ in $\mathrm{Fe}-\mathrm{Cr}-\mathrm{Ni}$ ternary system alloy.

Table 1 Chemical compositions of powders used.

\begin{tabular}{c|c|c|c|c|c|c}
\hline & $\mathrm{Cr}$ & $\mathrm{Ni}$ & $\mathrm{C}$ & $\mathrm{Si}$ & $\mathrm{Mn}$ & $\mathrm{Fe}$ \\
\hline$\delta$ powder & 27.39 & 7.22 & 0.007 & 0.010 & 0.009 & bal. \\
\hline$\gamma$ powder & 19.64 & 12.14 & 0.007 & 0.010 & 0.061 & bal. \\
\hline
\end{tabular}
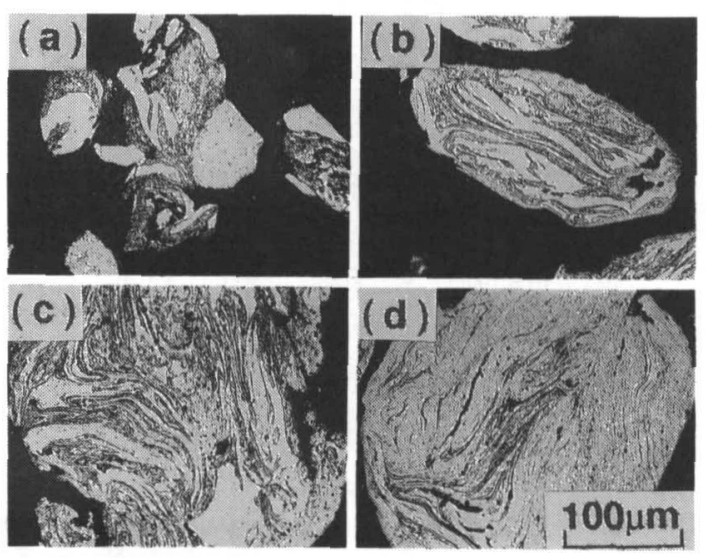

Photo. 1 Microstrucutures of $\gamma-50$ vol\% $\delta$ premixed powder ball-milled for (a) $10.8 \mathrm{ks}$, (b) $36 \mathrm{ks}$, (c) $108 \mathrm{ks}$ and (d) $360 \mathrm{ks}$.

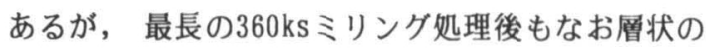
組織が観察された。

Fig. 2は, $\gamma-50$ vol\% $\delta$ 混合粉末のミリングにと もなうX線回折パターンの変化を示す． $\gamma$ 相の回折 線ピークに着目すると, ミリング時間が長くなるに つれてピークは小さくなり, 消滅していく傾向にあ る.このことはミリングにより混合粉の中の $\gamma$ 相が bcc相に変化していくことを物語っている. また, ミ リング時間が長くなるにつれて各回折線ピークの幅 が広がっているが, これはミリングによって粉末に 


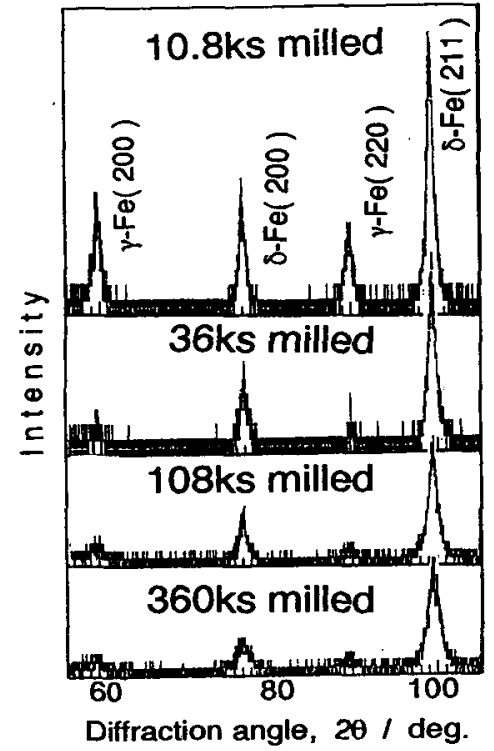

Fig. 2 Change in $X$-ray diffraction pattern with ball-milling in $\gamma-50$ vol\% $\delta$ premixed powder.

大きな䄳が付与されたことを意味している．Fig．3 に $\gamma$ 粉のみ，ならひに $\gamma-70$ vol\% $\delta$ 混合粉のミリン クにともなうbcc相量の変化を示す. $\gamma$ 粉のみでも ミリング中に基地相は，fccからbcc相へと変化し いる． bcc相の量はミリング時間が $10.8 \mathrm{ks}$ から $36 \mathrm{ks}$ にかけて急激に增加し，その後ミリング時間が長く なるにつれて徐々に增加していく傾向にはあるが， その変化は小さい，平山ら ${ }^{4)}$ は，マルテンサイト( $\left.\alpha^{\prime}\right)$ 変態に関する既知の熱力学的数值から $\mathrm{Fe}-\mathrm{Cr}-\mathrm{Ni}$ 系ステンレス鋼の $\alpha^{\prime}$ 変態に対する化学組成の影響 を $\mathrm{Ni}$ 当量 $(\mathrm{Ni}+0.65 \mathrm{Cr}+0.98 \mathrm{Mo}+1.65 \mathrm{Mn}+0.35 \mathrm{Si}+12.6 \mathrm{C}$ ; mass\% )で整理し,このNi当量が約20.7〜25.7\%の 組成の鐥では準安定な $\gamma$ 単相組織が得られ, 冷間加 工により 加工誘起 $\alpha^{\prime}$ 変態が起こることを報告して いる. 本実験で使用した $\gamma$ 粉のNi当量は $25.4 \%$ \%て あり, ミリング中のbcc構造への変化が加工誘起 $\alpha^{\prime}$ 変態に起因することは明らかである。また加工誘起 $\alpha^{\prime}$ 量は，合金の成分だけでなく加えられる歪の量 にも対応して增加することはいうまでもないが， $\gamma$ 粉と同組成の 板材の場合, $75 \%$ 強加工を施しても 誘起される $\alpha^{\prime}$ 量はたかだか10\%程度である。 $360 \mathrm{ks}$ ミリング処理した $\gamma$ 粉の $\alpha^{\prime}$ 量は約60んにも達してお り,このことは、ミリングによって粉末に導入され た歪の量かいかに大きいかを物語っている。一方 $\gamma$ $-70 v_{0} 1 \% \delta$ 混合粉についてもbcc相の増加挙動は $\gamma$ 粉

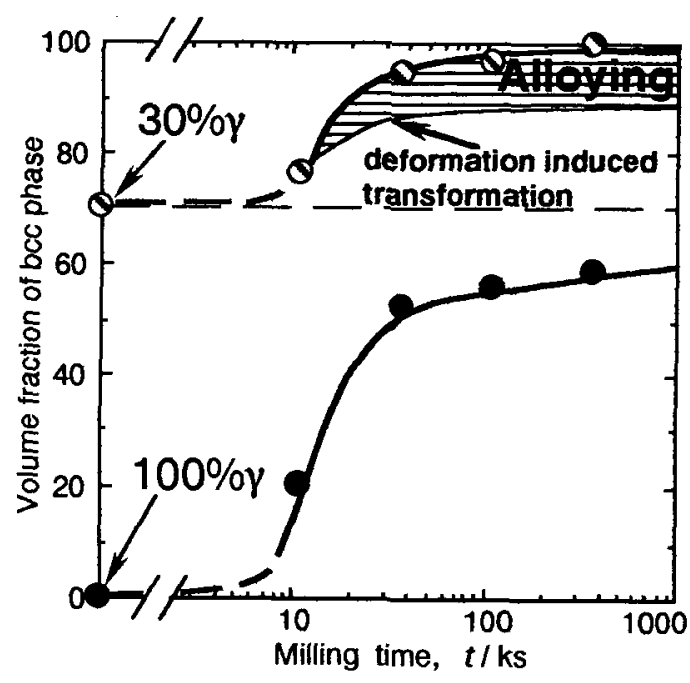

Fig. 3 Change in the volume fraction of bcc phase with ball-milling in $\gamma$ powder and $\gamma-70$ vol\% $\delta$ premixed powder. Hatched part shows the amount of bcc Phase formed by mechanical alloying.

のみの場合と類似しているか， 相違点は $360 \mathrm{ks} の ミ$ リングでbcc単相になっている点である．混合粉に おける $\boldsymbol{\gamma}$ 相の変化が $\gamma$ 相粉の加工誘起 $\alpha^{\prime}$ 変態のみ で進行すると仮定して，ミリングにともなうbcc相 の変化量を $\gamma$ 粉のみの場合のテータから推定すると 図中の細実線で示した曲線となり，実測值より得ら れた曲線よりもかなり少ない。このことは $\gamma$ 相の bcc相への変化が, 加工誘起 $\alpha^{\prime}$ 変態以外の別のプロ セスでも進行していることを示している，つまり， 実測値と加工誘起 $\alpha^{\prime}$ 変態線との差（図中のハッチン グで示した部分)は， $\gamma$ 相と $\delta$ 相が互いに反応して メカニカルアロイングのプロセスで形成された bcc 相の量に対応すると考えられ，ミリング時間が長く なるにつれて增加している．Fig．4に，種々の割合

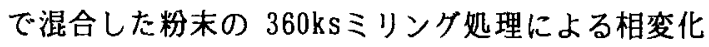
を示す．図中の破線が本来の混合粉の相比である が，ミリング观理を施すことによりいずれの混合粉 も $\gamma$ 相はbcc相へと変化していく傾向にある．前述 の場合と同様に加工誘起 $\alpha^{\prime}$ 量を差し引いてメカ二 カルアロイングのプロセスで形成されたbcc相 量を 推定すると，図中のハッチングで示した部分 とな る.メカニカルアロイングによって形成されるbcc 相量は $\delta$ 相粉の割合が多くなるほと増加しており, $\delta-70 v 01 \% \gamma$ 混合粉では bcc単相となっている.こ のことは合金化が $\delta$ と粉末の界面反応で起こって 


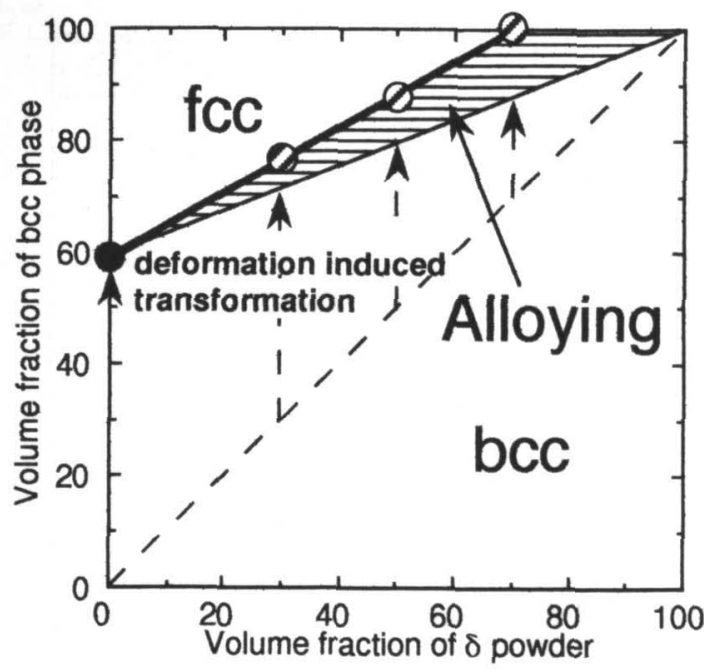

Fig. 4 Change in the volume fraction of bcc phase in premixed powders with $360 \mathrm{ks}$ ballmilling.

いることを示唆しており， $\gamma$ 相が $\delta$ 相と接触する機 会が多いほど bcc相化が促進されるものと解䊅でき る.

一方Photo．2は，360ksミリング処理によってbcc 単相となった $\gamma-70 v_{0} 1 \% \delta$ 混合粉の断面のEPMA分析 の結果を示す. 写真中の白線に沿って (a) $\mathrm{Cr}-\mathrm{K} \alpha$ 線 と (b) Ni-K $\alpha$ 線の線分析を行っているが, 腐食部で は高Cr低Niとなっているのに対して，無腐食部の島 状に取り残された部分では低Cr高Niとなっている.

つまり，ミリング処理によって基地相がbcc単相に 変化したにもかかわらず， $\mathrm{Cr}, \mathrm{Ni}$ などの合金元素は いまだ均一化していないわけである． 低 $\mathrm{Cr}$ 高Ni領 域は明らかに単相組織であることから加工誘起 $\alpha^{\prime}$ に相当すると考えられる，一方高Cr低Ni領域の組織 は，微細な層状組織を呈していることから， $\delta$ 相と ならびに $\delta$ 相と $\gamma$ 相がメカニカルアロイングのプロ セスで反応して生成したbcc相の 混合組織に相当す ると思われる.

以上共䡉組成の $\delta$ およひ $\gamma$ 粉の混合粉末をミリン ク処理すると $\gamma$ 相粉の加工誘起 $\alpha^{\prime}$ 変態およひ $\delta$ と $\gamma$ 相の界面におけるメカニカルアロイングによって $\gamma$ 相がbcc相に変化していくことを示したが，この 界面での合金化について自由エネルギーの観点から 考察する.Fig. 5は, Kaufmanの式 ${ }^{51}$ から算出した $300 K$ での $\delta$ 相と $\gamma$ 相の Gibbes自由エネルギー差（ $\Delta \mathrm{G}^{\mathrm{fcc}-\mathrm{bcc})}$ )の合金成分による変化を $\delta$ 粉の混合 割合で整理したものである. $\Delta \mathrm{G}$ の值は合金粉の混

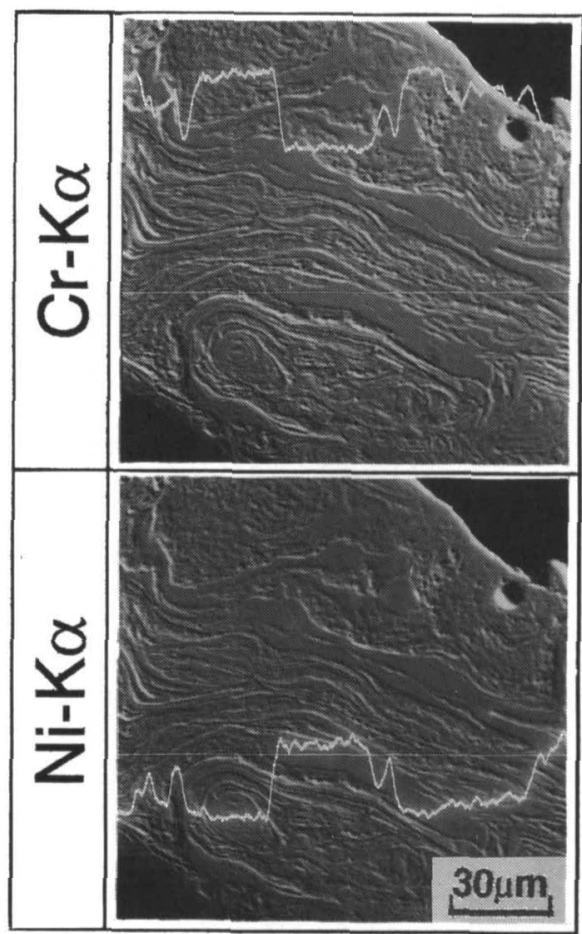

Photo. 2 EPMA line analysis profiles of $\mathrm{Cr}$ and $\mathrm{Ni}$ in $\gamma$-70vol\% $\delta$ premixed powder with $360 \mathrm{ks}$ ball-milling.

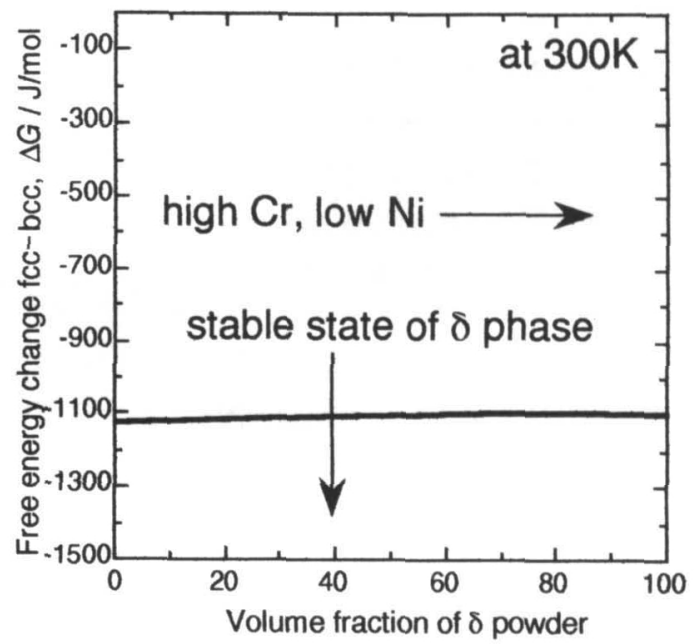

Fig. 5 Relation between the volume fraction of $\delta$ powder and the Gibbes free energy change for the austenite to ferrite transformation at $300 \mathrm{~K}$ in premixed $(\delta+\gamma)$ powder.

合割合 (成分)にほとんど依存せず，-1100J/mol程度 の一定値を示す．ミリングによる $\gamma$ 相のbcc相化は, このエネルギー差を駆動力としてエネルギー的に最 も安定なbcc相に加工誘起変態や メカニカルアロイ 
ングのプロセスを経て変化していく現象として理解 できる.ただ $\delta$ 粉と $\gamma$ 粉をどのような割合で混合し ても自由エネルギー差はほとんど変化しないことか ら，化学的な自由エネルギーに低下がない場合でも ミリングにより機械的なエネルキーを付与すれば合 金化することがわかり，これは注目すべき事実であ る.

以上の結果をまとめると，Fig．6に示すように， 基地相がbcc単相となった粉末では大きく分けて3夕 イプのbcc相が存在すると考えられる. 前揭Photo.2 で示した加工誘起 $\alpha^{\prime}$ 変態によって生成したbcc相( 低Cr高Ni部)，合金化していない $\delta$ 粉のbcc相(高 $\mathrm{Cr}$ 低Ni），ならひに $\delta$ との界面でメカニカルアロイ ングによって形成されたbcc相（上記 2 相の中間組 成)である.このbcc単相の粉末にさらにミリング姏 理を施していくと，これらの3 種類のbcc相の混合 がさらに進み，最終的に合金元素も均一化したbcc 単相の粉末となることが予想される. 以上のように この共䡉組成の $\delta$ およひ $\gamma$ ステンレス鋼粉の混合粉 末をボールミリングする手法では, メカニカルアロ イングおよび加工誘起 $\alpha$ '変態によって $\gamma$ 相がbcc相 に変化するため, 室温で $\delta$ と相が微細に混合した 2 相組織を得ることは困難なことが明かとなった。 また本結果は, ミリングした粉末の基地相が単相に なったとしても，組成までもが均一であるとはいえ ない例を示しており，ミリングによる粉末の結晶構 造の変化と組織や成分の変化は別の問題として考え

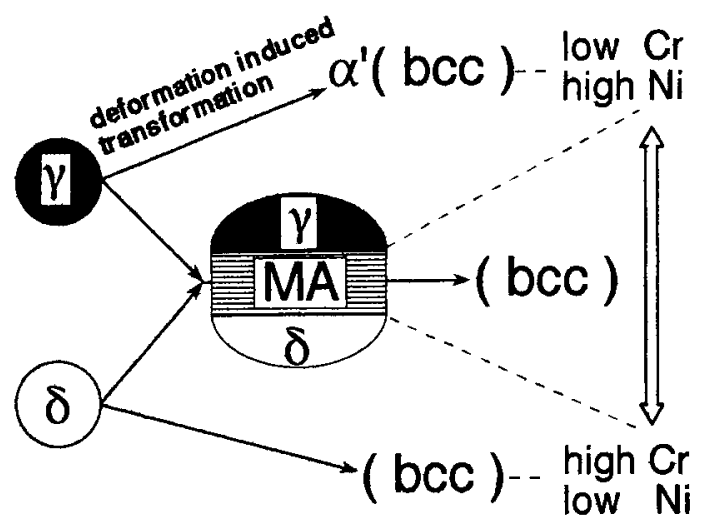

Fig. 6 Schematic illustration showing the change to bcc phase with ball-milling in premixed $(\delta+\gamma)$ powder.
る必要がある点を指摘している.

\section{IV 蛣 言}

$\mathrm{Fe}-\mathrm{Cr}-\mathrm{Ni} 3$ 元系状態图の1473Kにおける等温断面図 上で共䡉する組成のフェライト $(\delta)$ およひオーステ ナイト $(\gamma)$ ステンレス鋼粉の混合粉についてボール ミリング過程の粉末の組織変化を検討した結果, 次 のような結論を得た。

1）長時間ミリング処理した粉末ほど基地組織は 微細化する傾向にあるが, 長時間ミリング処理して bcc単相となった粉末でも層状組織が残存する傾向 がみられた。また層状組織に対応して，CrとNiの分 布も不均一であった。

2） $\delta$ と $\gamma$ 粉を混合した粉末では， $\delta$ と $\gamma$ 粉の混 合割合に関係なく 基地相がbcc単相に変化していく 傾向を示し，この挙動は $\delta$ 粉の割合が高い混合粉末 ほど顕著になる。

3） $\gamma$ 相のbcc相への変化は, fcc $\Rightarrow b c c の$ 自由エネ ルギー差(約-1100J/mo1)を駆動力とした， $\gamma$ 粉の加 工誘起マルテンサイト変態, およひ $\delta$ と $\gamma$ 粉の界面 でのメカニカルアロイングの効果が相乗して起こっ たものである.

最後に実験に使用した粉末を提供していただいた 東洋鋼钣株式会社に深く感謝いたします。また， 本研究のEPMA分析は, 本学工学部のIMA特別実験室 にて行ったことを記しておきます。

\section{文 塥}

1) 木村勇次, 高木節雄, 鎌田政智：日本金属学会 講演概要集 (1992，10) 162 .

2) M. Hasebe and T. Nisizawa: App/ications of phase diagrats in metallurgy and ceramics. $v o / .2$, National Bureau of Standards, (1978) 910 .

3）鎌田政智, 徳永洋一：日本金属学会誌, 55(1991) 887 .

4) 平山俊成, 小切間正彦：日本金属学会誌, 34(1970) 507.

5) L. Kaufman : Trans. Metall. Soc. AIME, 215(1959) 218. 